Supplement of Biogeosciences, 14, 2755-2765, 2017

https://doi.org/10.5194/bg-14-2755-2017-supplement

(C) Author(s) 2017. This work is distributed under

the Creative Commons Attribution 3.0 License.

(c) (1)

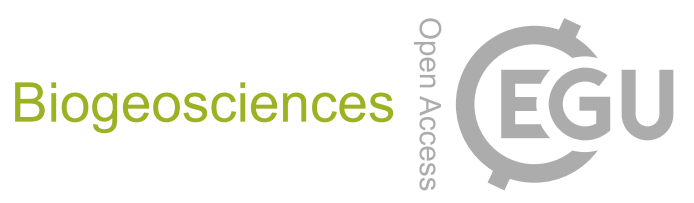

Supplement of

\title{
Changing patterns of fire occurrence in proximity to forest edges, roads and rivers between NW Amazonian countries
}

Dolors Armenteras et al.

Correspondence to: Dolors Armenteras (darmenterasp@unal.edu.co)

The copyright of individual parts of the supplement might differ from the CC BY 3.0 License. 
Supplement 1. Table S1. Results of the Kolmogorov-Smirnov tests between the observed and the null model for distances of fire occurrences to roads and rivers in each country.

\begin{tabular}{llcl}
\hline Country & Accessibility & D-statistics & p-value \\
\hline Brazil & rivers & 0.633 & $<0.01$ \\
Brazil & roads & 0.706 & $<0.01$ \\
Colombia & rivers & 0.620 & $<0.01$ \\
Colombia & roads & 0.644 & $<0.01$ \\
Ecuador & rivers & 0.706 & $<0.01$ \\
Ecuador & roads & 0.768 & $<0.01$ \\
Peru & rivers & 0.651 & $<0.01$ \\
Peru & roads & 0.713 & $<0.01$ \\
Venezuela & rivers & 0.702 & $<0.01$
\end{tabular}


Supplement 2. Pairwise distances between CFD curves for countries in Figures 4.

Table S2: Distances between CFD curves in Fig. 4A.

\begin{tabular}{|l|c|c|c|c|}
\hline & Brazil & Colombia & Ecuador & Peru \\
\hline Colombia & 0.01 & & & \\
\hline Ecuador & 0.39 & 0.38 & & \\
\hline Peru & 0.11 & 0.10 & 0.29 & \\
\hline Venezuela & 0.21 & 0.20 & 0.20 & 0.10 \\
\hline
\end{tabular}

Table S3: Distances between CFD curves in Fig. 4B.

\begin{tabular}{|l|c|c|c|}
\hline & Brazil & Colombia & Ecuador \\
\hline Colombia & 0.29 & & \\
\hline Ecuador & 0.20 & 0.30 & \\
\hline Peru & 0.09 & 0.23 & 0.15 \\
\hline
\end{tabular}

Table S4: Distances between CFD curves in Fig. 4C. 


\begin{tabular}{|l|c|c|c|c|}
\hline & Brazil & Colombia & Ecuador & Peru \\
\hline Colombia & 0.03 & & & \\
\hline Ecuador & 0.08 & 0.06 & & \\
\hline Peru & 0.03 & 0.01 & 0.05 & \\
\hline Venezuela & 0.03 & 0.01 & 0.07 & 0.02 \\
\hline
\end{tabular}

Table S5: Distances between CFD curves in Fig. 4D.

\begin{tabular}{|l|c|c|c|}
\hline & Brazil & Colombia & Ecuador \\
\hline Colombia & 0.15 & & \\
\hline Ecuador & 0.48 & 0.40 & \\
\hline Peru & 0.32 & 0.24 & 0.21 \\
\hline
\end{tabular}


Supplement 3. Table S6. Results of the Kolmogorov-Smirnov tests between the observed and the null model for distances of fire occurrence to forest edge (outside or inside the forest) in each country.

\begin{tabular}{llcc}
\hline Country & \multicolumn{1}{c}{ Forest edge } & D-statistics & p-value \\
\hline Brazil & outside the forest & 0.969 & $<0.01$ \\
Brazil & inside the forest & 0.801 & $<0.01$ \\
Colombia & outside the forest & 0.938 & $<0.01$ \\
Colombia & inside the forest & 0.768 & $<0.01$ \\
Ecuador & outside the forest & 0.978 & $<0.01$ \\
Ecuador & inside the forest & 0.705 & $<0.01$ \\
Peru & outside the forest & 0.940 & $<0.01$ \\
Peru & inside the forest & 0.687 & $<0.01$ \\
Venezuela & outside the forest & 0.927 & $<0.01$ \\
Venezuela & inside the forest & 0.737 & $<0.01$ \\
\hline
\end{tabular}

